La Porta, R., Florencio Lopez-de-Silanes, Andrei Shleifer, and Robert W. Vishny. 2002. Investor Protection and Corporate Valuation. Journal of Finance 57, 1147-1170.

Lemmon, Michael L., and Karl V. Lins. 2003. Ownership Structure, Corporate Governance and Firm Value: Evidence From The East Asian Financial Crisis. Journal of Finance, 58: $1445-1468$.

Mitton, T., 2002. A Cross-Firm Analysis The Impact of Corporate Governance on The East Asian Financial Crisis. Journal of Financial Economics, 64: 215-241

Na'im, Ainun. 2006. Special Purpose Vehicle Institution: Their Business and Accounting Implications. Gadjah Mada International Journal of Business, 8(1): 1-19

Nenova, T., 2000. The Value of Corporate Votes and Control Benefits: A Cross-Country Analysis. Unpublised Working Paper. Havard University.

Ohlson, J.A., 1995. Earnings, book values, and dividends in equity valuation. Contemporary Accounting Research 11, 661-687

Shin, H., and Y.S. Park. 1999. Financing Constraint and Internal Capital Market: Evidence from Korean Chaebols. Journal of Corporate Finance, 5: 169-194.

Shleifer, Andrei and Robert W. Vishny. 1994. Politicians and Firms. Quarterly Journal of Economics, 109: 995-1025.

Shleifer, Andrei dan Robert W. Vishny. 1997. A Survey of Corporate Governance. Journal of Finance, 52(2): 737-783

Stimpert, J.L., dan Irene M. Duhaime. 1997. Seeing The Big Picture: The Influence of Industry, Diversification and Business Strategy on Performance. Academy of Management Journal, 40(3): 560-583

\section{PENGEMBANGAN ALAT UKUR KESANTUNAN BAHASA INDONESIA DALAM INTERAKSI SOSIAL FORMAL BERSEMUKA}

\author{
Oleh: \\ Zamzani, Tadkiroatun Musfiroh, Siti Maslakhah, \\ Ari Listiyorini, dan Yayuk Eny Rahayu \\ Universitas Negeri Yogyakarta \\ email: zamzani_55@yahoo.com
}

\section{Abstrak}

Penelitian ini bertujuan (1) mengembangkan alat ukur kesantuanan bahasa Indonesia dalam tuturan formal bersemuka; (2) melakukan uji lapangan terbatas terhadap alat ukur kesantunan bahasa Indonesia dalam interaksi sosial formal bersemuka; (3) mengembangkan alat ukur kesantunan dalam bentuk VCD interaktif dengan program komputer. Adapun manfaat yang dapat dipetik adalah (1) acuan untuk mengukur kesopanan dalam bertindak tutur formal bersemuka, (2) gambaran alat ukur kesantunan formal bersemuka (3) acuan mengukur derajat kesantunan atau kesopanan pada pengguna bahasa Indonesia dalam berbagai kelas sosial.

Penelitian ini didasarkan pada empat alasan. Pertama, kesantunan berbahasa merupakan unsur penting dalam membina karakter positif masyarakat tutur Indonesia. Kedua, selalu ada potensi negatif dalam komunikasi lintas kultur dan lintas sosial karena belum ada alat ukur kesantunan dalam bahasa Indonesia. Ketiga, prinsip kesantunan berbahasa yang ada masih mengacu Barat yang belum tentu sesuai dengan kultur Indonesia. Keempat, alat ukur kesantunan dapat dimanfaatkan sebagai media pembina kesantunan berbahasa dalam berbagai ranah dan satuan pendidikan.

Sebagai pendekatannya, digunakan pendekatan riset dan pengembangannya atau Research and Development $(R \& D)$. Penelitian ini dilaksanakan selama tiga tahun. Pada penelitian tahun pertama telah dihasilkan indikator-indikator kesantunan berbahasa Indonesia. Pada penelitian tahun kedua dilakukan pengembangan alat ukur kesantunan yang didasarkan pada indikator keuniversalan konsep kesantunan masyarakat penutur bahasa Indonesia dalam situasi formal bersemuka 
yang ditemukan di tahun pertama. Pada akhirnya, pada penelitian tahun ketiga ini dihasilkan alat ukur kesantunan berbahasa Indonesia dalam bentuk VCD interaktif dengan program computer.

Pada penelitian tahun ketiga ini, yang telah dicapai adalah menghasilkan dan menggandakan produk alat ukur dalam bentuk VCD interaktif serta melakukan sosialisasi alat ukur melalui pelatihan terhadap guru, dosen, mahasiswa, dan instansi-instansi lain calon pengguna alat ukur ini.

\section{PENDAHULUAN}

Kesantunan berbahasa berperanan penting dalam proses komunikasi. Dengan penggunaan kesantunan berbahasa pembicara dan pendengar akan merasa saling dihargai dalam proses komunikasi. Kesantunan berbahasa, yang dapat dianggap sebagai bagian dari kaidah-kaidah sosial dan juga sebagai strategi, perlu diperhatikan dalam komunikasi bahasa. Seseorang yang akan meminta orang lain untuk melakukan sesuatu, misalnya, akan dihadapkan kepada pilihan-pilihan ujaran yang tepat untuk situasi yang dihadapi.

Kesantunan berbahasa memiliki peran penting dalam membina karakter positif penuturnya, sekaligus menunjukkan jati diri bangsa. Walaupun hampir mustahil membuat generalisasi kesantunan dalam semua wilayah, alat ukur penentu kesantunan dalam situasi formal baik lisan maupun tertulis serta situasi nonformal (yang tidak menjangkau wilayah intimate) dapat dibuat dan diperlukan keberadaannya. Alat ukur ini akan sangat membantu mengatasi "bias komunikasi" terutama yang timbul akibat perbedaan kultur setempat dan lintas sosial penutur. Alat ukur ini akan membantu keberadaan bahasa Indonesia sebagai alat pembina karakter penuturnya. Dengan memerhatikan semua uraian di atas, penelitian multiyears ini diajukan.

Penelitian ini memiliki tujuan secara bertahap dalam setiap tahunnya, yaitu sebagai berikut.

1. Mengidentifikasi bentuk-bentuk tindak tutur yang bernilai kesantunan bersemuka.
2. Mengidentifikasi indikator-indikator kesantunan bahasa Indonesia dalam interaksi sosial bersemuka yang dibutuhkan penutur bahasa Indonesia.

3. Menyusun indikator kesantunan untuk dikembangkan sebagai alat ukur kesantunan bahasa Indonesia.

4. Mengembangkan alat ukur kesantunan bahasa Indonesia dalam interaksi sosial formal baik yang bersemuka maupun nonbersemuka.

5. Melakukan validasi dan uji lapangan terbatas terhadap alat ukur kesantunan bahasa Indonesia dalam interaksi sosial formal baik yang bersemuka maupun nonbersemuka.

6. Mengembangkan alat ukur kesantunan dalam bentuk buku.

7. Menyempurnakan alat ukur kesantunan bahasa Indonesia dalam interaksi sosial formal baik yang bersemuka dalam bentuk program komputer dan buku, serta memperbanyak produk.

8. Melakukan sosialisasi alat ukur kesantunan bahasa Indonesia dalam interaksi sosial formal baik yang bersemuka dalam bentuk pelatihan kepada pendidik (guru dan dosen), pengambil kebijakan, balai bahasa, dan instansi yang membutuhkan.

Fenomena sopan santun tidak dapat dilepaskan dari pranata kebudayaan sebuah bahasa. Penggunaan bahasa dapat menunjukkan kebudayaan, nilai-nilai yang dianut, dan keyakinan agama seseorang. Melalui bahasa, dapat diketahui karakter seseorang, seperti sifat terbuka atau tidaknya, jalan pikiran, sopan santun, bahkan kejujurannya (Kawulusan, 1998).

Sebagai sebuah fenomena relatif, sopan-santun tidak mudah untuk digeneralisasikan. Sopan dan santun dalam suatu kultur belum tentu bernilai sama dalam kultur yang lain. Sapaan yang bernilai kesantunan tinggi dalam suatu budaya, mungkin justru tidak dikenal dalam budaya yang lain. Meskipun demikian, ada ciri-ciri universal dalam kesantunan berbahasa yang dapat diterapkan dalam banyak budaya. 
Acuan kesantunan berbahasa dengan bahasa Indonesia memiliki fungsi strategis. Pertama, penutur bahasa Indonesia akan memiliki "aturan" berbahasa. Kedua, penutur bahasa Indonesia memiliki kesempatan untuk melakukan refleksi diri apakah tuturannya sudah sesuai dengan kaidah kesantunan bahasa. Ketiga, para pendidik memiliki pegangan untuk memberikan pembelajaran kesantunan berbahasa. Keempat, acuan kesantunan berbahasa dapat beriringan dengan aturan berbahasa secara baik dan benar (dalam konteks formal).

Fenomena di atas menunjukkan bahwa saat ini, sopan santun berbahasa perlu mendapatkan perhatian. Meskipun demikian, fakta menunjukkan perilaku verbal saat ini, dinilai mulai tidak memperhatikan nilai kesopanan dan kesantunan berbahasa, pun dalam berkomunikasi melalui telepon dan handphone. Ketiadaan sapaan, kata penghalus, topik yang tidak pantas, pilihan kata, cara berbicara yang tidak memerhatikan pola pergiliran bicara, menyakiti, kritis pedas, instruksi bossy, pemerasan verbal, intimidasi, ancaman, merupakan sebagian contoh fenomena riil berbahasa di lapangan. Kebutuhan akan acuan berperilaku verbal yang memenuhi kaidah sopan santun pun semakin dirasa mendesak.

Penelitian ini berusaha menjembatani kondisi di atas. Adapun manfaat dan keutamaan penelitian ini adalah sebagai berikut.

1. Hasil penelitian dapat digunakan sebagai refleksi bagi penutur bahasa Indonesia, dari berbagai strata sosial, jenis kelamin, latar belakang pendidikan, dan profesi.

2. Alat ukur yang dihasilkan dapat dijadikan acuan dalam bertindak tutur bahasa Indonesia yang santun, baik dalam situasi formal, konsultatif, maupun casual, baik lisan maupun nonlisan.

3. Alat ukur yang dihasilkan dapat dijadikan pedoman bagi pendidik (guru dan dosen) dalam mendidik siswa dan mahasiswa agar berbahasa secara santun serta menangani kasus ketidaksantunan berbicara, berpidato, berdiskusi, rapat.

4. Alat ukur yang dihasilkan menjadi pengayaan penelitian dan teori pragmatik.

Penelitian tahun ketiga ini dapat dimanfaatkan secara khusus untuk pedoman alat ukur atau penilaian dalam mengukur kesantunan dari masing-masing individu berdasarkan bentukbentuk tuturan yang disajikan dalam alat ukur kesantunan formal bersemuka.

Selain tujuan praktis, hasil penelitian ini juga dapat digunakan sebagai acuan untuk mengukur kesopanan dalam bertindak tutur formal bersemuka, gambaran alat ukur kesantunan formal bersemuka dan acauan mengukur derajat kesantunan formal bersemuka pada pengguna bahasa Indonesia dalam berbagai kelas sosial

\section{CARA PENELITIAN}

Penelitian ini mempergunakan pendekatan riset dan pengembangannya atau Research and Development ( $\mathrm{R} \& \mathrm{D})$. Pendekatan yang digunakan untuk tiap-tiap tahun disesuaikan dengan tujuan yang ingin dicapai. Penelitian tahun pertama, yang telah dicapai, bertujuan untuk melakukan identifikasi kebutuhan (need assesment) masyarakat tutur bahasa Indonesia terhadap kesantunan dalam berbahasa, lalu membuat indikator keuniversalan konsep kesantunan masyarakat penutur bahasa Indonesia dalam situasi formal bersemuka, serta mengembang alat ukur kesantunan yang awal dalam bentuk draf alat ukur tentatif. Penelitian Tahun kedua yang telah dicapai adalah mengembangkan alat ukur yang didasarkan pada indikator kesantunan yang sudah dibuat pada tahun pertama. Alat ukur divalidasi oelh ahli dan pengguna dalam bentuk desk evaluation dan FGD. Alat ukur kesantunan juga diujicobakan dalam bentuk tes dalam berbagai lapangan penelitian. Alat ukur berupa tes yang 
telah direvisi diolah dalam bentuk buku. Penelitian tahun ketiga yang telah dicapai adalah menyempurnakan dan menggandakan produk alat ukur dalam bentuk VCD interaktif serta melakukan sosialisasi alat ukur melalui pelatihan terhadap guru, dosen, mahasiswa, dan instansi-instansi lain calon pengguna alat ukur ini

Prosedur pengembangan diadaptasikan dari R \& D Borg and Gall (2003) dan dirancang dalam tiga tahun, yakni:

1. Studi pendahuluan yang terkait dengan tujuan untuk program. Dalam hal ini dilakukan identifikasi kebutuhan kesantunan bahasa Indonesia.

2. Melakukan perancangan alat ukur kesantunan bahasa Indonesia.

3. Mengembangkan produk alat ukur awal

4. Melakukan uji coba lapangan permulaan

5. Melakukan penyempurnaan berdasarkan hasil uji coba lapangan permulaan

6. Melakukan uji coba lapangan luas

7. Melakukan revisi (penyempurnaan) alat ukur berdasarkan hasil uji lapangan utama

8. Mengembangkan alat ukur menjadi produk yang operasional (dapat dimanfaatkan langsung oleh khayalak)

9. Menyempurnakan produk dan memproduksi secara massal

10. Melakukan diseminasi dan implementasi produk.

Lokasi penelitian ini adalah Yogyakarta, meliputi Sleman, Kota, Gunung Kidul, Kulon Progo dan Bantul. Pemilihan lokasi didasarkan pada kebutuhan atau tujuan. Wilayah-wilayah yang dihuni warga dari multisuku dan multietnis juga dipilih selain lembaga pendidikan dan kampus. Kriteria yang digunakan setidaktidaknya meliputi satu dari tiga syarat, yakni penutur bahasa Indonesia aktif (baik sebagai bahasa pertama maupun kedua), latar belakang pendidikan, dan anggota suatu masyarakat atau wacana tutur tertentu, khususnya komunitas bahasa Indonesia.
Teknik pengumpulan data disesuaikan dengan tujuan penelitian tiap tahun. Pada tahun ketiga, alat ukur diproduksi dalam bentuk program komputer. Data uji kelayakan produk dijaring dengan instrumen kuesioner serta panduan wawancara dan observasi. Beberapa penyesuaian masih diperlukan, terkait dengan performa program alat ukur kesantunan bahasa sehingga menarik dan mudah dipahami. Penyempurnaan dilakukan dalam hal pengeditan bahasa, lay-out, dan ilustrasi. Teknik yang dilakukan adalah observasi, editing, dan proofreading. Produk yang sempurna kemudian dicetak secara massal. Produk massal dimanfaatkan untuk diseminasi (dan sosialisasi dalam bentuk pelatihan) di kalangan penutur bahasa Indonesia. Untuk tujuan ini data dijaring dengan angket, wawancara, observasi, dan dokumentasi.

\section{PEMBAHASAN}

Berdasarkan studi tahun pertama diperoleh sejumlah indikator kesantunan bahasa Indonesia dalam interaksi sosial formal bersemuka. Indikator tersebut terbagi ke dalam lima ranah interaksi, yakni (1) proses belajar mengajar (PBM), (2) pertemuan resmi, (3) kegiatan akademik lain (nonPBM), (4) upacara adat dan seremonial, (5) transaksi, negosiasi, dan pelayanan publik. Indikator kesantunan dalam lima ranah tersebut dikategorikan ke dalam lima kategori, yaitu sangat sopan, sopan, agak sopan, tidak sopan, dan sangat tidak sopan.

Berdasarkan hasil penelitian diketahui bahwa indikator kesopanan sebuah tuturan ditentukan oleh berbagai faktor, yakni penggunaan kata-kata, ada tidaknya sapaan, tujuan berbicara, tepattidaknya situasi, sikap diri (angkuh, sombong), kejujuran dan ketidakjujuran, kevulgaran, efek pada pendengar, pendengar, otoritas kelas sosial, dan kecukupan tuturan. Apabila dicermati lebih jauh, sesuai dengan 4 syarat prinsip yang digunakan sebagai titik tumpu penelitian ini (kesopanan, kerjasama, kesantunan formal, dan tenggang rasa), penilaian atas sopan-tidak sopan 
memiliki indikator positif dan negatif. Indikator-indikator kesantunan tersebut seringkali tumpang tindih dan menyebabkan perbedaan persepsi nilai kesantunan bagi para responden. Sebuah peristiwa tutur, tuturan-tuturan antara dua penutur, adakalanya memiliki lebih dari 1 indikator yang bertentangan, sehingga interpretasi pendengarnya pun berbeda. Sebuah kritik pedas yang diberikan dosen dinilai sopan karena dosen dinilai memiliki otoritas. Sebuah masukan yang agak menyakitkan dinilai sopan karena memiliki indikator kejujuran. Sebuah peringatan yang jujur dinilai tidak sopan karena memiliki indikator kekurangajaran pada orang tua. Menolak dengan jujur dinilai tidak sopan karena memiliki indikator menolak kewajiban atau tugas.

Berbagai indikator kesantunan mengarah pada calon indikator yang berdimensi kultur. Pada proses PBM, misalnya, dosen dan guru adalah pemegang otoritas yang menentukan nilai kesantunan sebuah tuturan. Guru boleh memarahi siswa, dan hal tersebut dinilai sopan, karena guru tersebut memiliki hak mendidik dan bertujuan positif. Murid protes berarti tidak sopan. Penilaian semacam ini terlihat lebih kentara pada responden yang justru bukan dari kalangan guru (petani, buruh, karywan). Hal demikian, nilai kesantunan guru-murid, tidak dapat diterapkan sepenuhnya pada kesantunan antara dosen-mahasiswa. Hubungan dosenmahasiswa dianggap lebih bernilai solidaritas dan relatif lebih sejajar daripada guru-murid. Oleh karena itu, tuturan dosen ke mahasiswa diharapkan lebih memerhatikan prinsip kesantunan, prinsip kerjasama, dan tenggang rasa.

Indikator-indikator tersebut menunjukkan bahwa prinsip kerjasama Grice, prinsip kesantunan Leech, prinsip kesantunan formal Mills, dan prinsip kesantunan Azis saling melengkapi untuk membentuk sebuah indikator kesantunan bahasa Indonesia Formal bersemuka.

Berdasarkan pembahasan di atas, diketahui bahwa terdapat beberapa indikator yang ditemukan dalam penelitian adalah (1) ketulusan, (2) otoritas, (3) kata-kata standar, dan (4) konvensi. Hal ini menunjukkan bahwa ketulusan (memiliki kaitan dengan prinsip kualitas tetapi mungkin berhadapan dengan prinsip kesantunan) dipilih responden sebagai indikator. Responden menilai, ketulusan (pujian tulus, masukan tulus) adalah sopan dan tidak berlebihan. Sebaliknya, pujian yang dibuat-buat, justru terasa tidak menyenangkan dan bahkan mungkin mempermalukan orang yang dipuji.

Otoritas pun merupakan indikator. Orang yang memiliki otoritas boleh berbicara agar keras, memerintah, memotong pembicaraan, mengkritik, melontarkan lelucon, karena mereka punya hak. Otoritas dianggap benar karena punya tujuan tertentu yang mulia. Membocorkan otoritas akan dianggap berontak, kurang ajar, tidak tahu diri. Murid yang melucu untuk guru dianggap tidak sopan, walaupun guru boleh melucu untuk muridnya.

Kata-kata standar merupakan salah satu indikator yang dimunculkan responden. Kata maaf, silakan, yang terhormat, bapak-ibu, menyanyikan, promovendus, ke belakang, dipersilakan, dan hadirin. Tuturan yang sopan diseyogyakan menggunakan katakata standar seperti itu dan menghindari bentuk-bentuk informal dan campur kode seperti ngomong, pipis, bobok, nyanyiin, mas yang diuji, dan sorry ya. Penggunaan kata-kata informal, bahasa daerah (yang bukan kode tinggi) dinilai sebagai pengingkaran konteks formal dan dianggap seenaknya sendiri.

Konvensi dalam konteks formal merupakan indikator kesantunan yang dipersyaratkan oleh responden. Dalam konteks yang benar-benar formal, topik, sikap, pilihan kata benar-benar harus dipatuhi. Humor dalam konteks formal tidak diperkenankan. Lelucon keakraban akan dinilai sebagai olok-olok dalam situasi formal. Seorang pembawa acara memiliki patokan berbicara. Demikian halnya dalam ujian, sidang perkara, rapat-rapat, debat publik, pidato, laporan resmi, sambutan, pembawa acara, konvensi 
harus dipahami dan dilaksanakan. Pelanggaran terhadap konteks formal akan dinilai sebagai ketidaksopanan dan uneducated.

Hasil penelitian tahun kedua menemukan kategorisasi bentuk-bentuk kesantunan berdasarkan skala kesantuan dalam alat ukur kesantunan formal bersemuka. Kategorisasi kesantunan didasarkan pada hasil penilaian alat ukur kesantunan bahasa Indonesia formal yang dilakukan oleh pengguna. Pengguna memberikan skor pada masing-masing pilihan untuk menentukan tingkat kesantunannya dalam lima topik bahasan. Skor penilaian dalam alat ukur ini diketegori dalam empat skala penilaian. Skala tersebut adalah :

(1) Skala sangat Santun : skor 250-200

(2) Skala santun : skor 199-150

(3) Skala tidak santun : skor 149-100

(4) Skala sangat tidak santun : skor $<100$

Tuturan-tuturan bahasa Indonesia memiliki karakteristik sebagai berikut.

\section{a. Kesantunan Sangat Tinggi (Sangat Sopan)}

Sebuah tuturan bahasa Indonesia formal bersemuka dikategorikan sangat sopan apabila memiliki indikatorindikator di antaranya adalah : sesuai dengan sifat / kebiasaan, menghargai orang lain, ada kata maaf, kalimat tepat dan realistis, keadaan yang memerlukan ketegasan, keadaan yang benar-benar terjadi / fakta, sindiran namun halus, pujian yang tulus, menyampaikan haknya dalam berpendapat, sesuai dengan situasi dan tempat, menggunakan kata yang halus / enak didengar, tidak menyinggung perasaan.

\section{b. Kesantunan Tinggi (Sopan)}

Sebuah tuturan bahasa Indonesia formal bersemuka dikategorikan sopan apabila memiliki indikator-indikator, di antaranya : sesuai konteks, sesuai prosedural, sesuai dengan sifat/keadaan pada umumnya, bertujuan untuk mendidik, objektif, disampaikan tanpa berbelit-belit, sesuai dengan haknya, kata-katanya halus, memuji sesuatu yang baik.

\section{c. Kesantunan Rendah (Tidak Sopan)}

Sebuah tuturan bahasa Indonesia formal bersemuka dikategorikan sopan apabila memiliki indikator-indikator, di antaranya adalah : posisi sejajar tetapi marah dan menggunakan nada tinggi, menyinggung orang lain, kata-kata tidak sopan/ tidak tepat /menyakitkan, membandingkan dengan orang/produk lain, merendahkan orang lain/superior, mempermalukan pihak lain, dan beberapa indikator lagi,

\section{d. Kesantunan Sangat Rendah (Sangat Tidak Sopan)}

Sebuah tuturan bahasa Indonesia formal bersemuka dikategorikan sangat tidak sopan apabila memiliki indikatorindikator, di antaranya adalah : tidak menghargai orang lain, kata-kata yang digunakan kasar, kurang ajar, tidak ada toleransi, ironi di depan umum, menjatuhkan orang lain, mempermalukan orang lain, tidak memakai etika, ngotot, mendebat pihak yang lebih memiliki otoritas, tidak melaksanakan kewajiban, diksi terlalu vulgar

Pada penelitian tahun ketiga ini, alat ukur kesantunan bahasa Indonesia dalam interaksi sosial formal bersemuka disempurnakan lagi dan dibuat dalam bentuk program komputer. Berikut ini deskripsi hasil penelitian atau produk pada tahun ketiga.

Pada tahun ketiga ini hal pertama yang dilakukan, yaitu menyempurnakan alat tes kesantunan yang telah dihasilkan pada tahun kedua. Revisi yang telah dilakukan terhadap draft buku tersebut adalah penambahan informasi setting lokasi dan waktu untuk menampakkan warna lokal. Kuisioner berujud wacana yang dilengkapi dialog dengan warna lokal yang ditampakkan di dalam wacana tersebut. Sebelum direvisi, draft berupa kuisioner tanpa menampakkan warna lokal. Dengan pertimbangan agar lebih mudah dikerjakan oleh pengguna dan agar diperoleh ukuran yang valid maka draft tersebut dilengkapi dengan informasi tempat dan 
waktu untuk menampakkan warna lokal. Selain itu, penyempurnaan lain yang dilakukan ialah pengacakan kembali pilihan jawaban dalam alat tersebut. Hal ini dilakukan karena pada alat tes tersebut ternyata masih terdapat kunci jawaban yang tidak diporsi secara baik, misalnya masih terdapat jawaban sopan pada kunci A berturut-turut sampai dengan tiga soal. Kekurangan lain misalnya masih terdapat kunci jawaban yang belum merata. Setelah penyempurnaan selesai dilakukan, tahap selanjutnya yaitu membuat alat tes tersebut dalam bentuk program komputer.

Kegiatan pertama yang dilakukan untuk pembuatan program komputer ini ialah perekaman alat tes tertulis yang telah disempurnakan tersebut dalam bentuk suara (tes secara verbal). Perekaman/ pengisian suara ini dilakukan oleh mahasiswa Program Studi Bahasa dan Sastra Indonesia FBS UNY yang berjumlah 5 orang. Pengisian suara dilakukan di studio musik. Teknis pengisian suara adalah sebagai berikut. Tahap pengantar alat tes yang berupa petunjuk dan contoh serta ilustrasi/ pernyataan setiap nomor tes dilakukan/ diisi oleh satu suara. Selanjutnya untuk pengisian suara dari setiap jawaban/ pilihan disesuaikan dengan konteksnya. Apabila jawaban A-E dengan satu partisipan perempuan/ laki-laki yang sama, maka pengisian suara dilakukan oleh satu suara mahasiswa perempuan/ laki-laki. Apabila partisipannya beberapa perempuan maka juga diisi oleh beberapa mahasiswa perempuan. Mahasiswa-mahasiswa tersebut hanya pada tahap mengisi suara sedangkan ilustrasi musik dilakukan oleh tim studio musik.

Pengisian suara tersebut sesuai dengan alat tes kesantunan, yang terdiri dari lima topik bidang interaksi formal bersemuka. Topik-topik tersebut, yaitu topik dalam proses belajar mengajar, topik pertemuan resmi, topik akademik lain non-PBM, topik upacara adat dan seremonial, dan topik transaksi dan negosiasi. Setelah proses pengisian suara selesai maka tahap selanjutnya, yaitu pembuatan program komputer agar alat tes tersebut bisa digunakan secara interaktif. Pembuatan program ini dilakukan oleh programmer.

Pada penelitian tahun ketiga ini dapat terwujud program komputer alat tes kesantunan bahasa Indonesia dalam interaksi formal bersemuka. Dari pemrograman ini dihasilkan lima keping VCD dengan lima bidang topik yang berbeda. Kelima keping VCD tersebut berturut-turut dengan judul proses belajar mengajar, pertemuan resmi, topik akademik lain non-PBM, upacara adat, dan transaksi dan negosiasi.

Untuk dapat mempergunakan alat tes ini diperlukan program komputer Macromedia Flash. Pengguna dapat memilih salah satu keping VCD dengan topik tertentu untuk dimasukkan dalam drive CD (CD rom) pada computer. Pada beberapa computer akan langsung muncul judul VCD, namun pada beberapa computer tidak otomatis muncul judul VCD tersebut. Apabila layar tidak secara otomatis menampilkannya, pengguna dapat mengeklik "window explorer" lalu diteruskan dengan "my computer", kemudian mengeklik file CD. Pada layar akan muncul judul salah satu topik dari VCD yang dipilih, misalnya "Kesantunan Berbahasa Indonesia dalam Pertemuan Resmi". Setelah muncul layar tersebut klik start yang ada di bagian pojok bawah. Layar yang nampak setelah diklik start berisi perintah mengerjakan soal dalam waktu 50 menit dan kolom pengisian identitas pengguna yang meliputi nama pengguna, tempat tanggal lahir pengguna, dan profesi pengguna. Identitas ini harus diisi untuk melangkah ke tahap selanjutnya. Setelah pengisian lengkap, pilih/ klik tanda masuk. Layar selanjutnya berisi petunjuk pengerjaan soal beserta contoh. Dalam layar ini akan muncul suara pengisi suara beserta teks petunjuk dan contohnya. Untuk mulai mengerjakan tes, pilih tanda SKIP.

Dalam tahap pengerjaan tes ini soal hanya dibacakan disampaikan pada pengguna, tidak nampak dalam layar komputer. Soal hanya berupa pernyataan secara verbal "Dengarkan soal 
berikut". Pernyataan ini berlaku untuk pertanyaan tes pada semua nomor. Yang nampak dalam layar computer hanyalah teks pilihan jawaban. Teks pilihan jawaban dimunculkan dalam layar komputer dengan pertimbangan apabila teks ini tidak muncul pengguna akan kesulitan mengingat-ingat jawaban. Hal ini dikarenakan banyak jawaban yang panjang dan jawaban bukan benar atau salah secara pasti tetapi tergantung pilihan pengguna. Setiap pengguna harus mengeklik/ memilih satu jawaban dari setiap nomor yang dibacakan. Apabila pengguna belum memilih atau mengeklik salah satu jawaban, maka soal berikutnya tidak akan muncul. Waktu yang disediakan untuk 50 soal setiap topik ialah 50 menit. Seandainya dalam waktu 50 menit pengguna belum selesai mengerjakan tes, maka soal yang tersisa dianggap belum dikerjakan. Tanggal dan waktu, serta tanda print dan exit tetap muncul di layar ini.

Setelah 50 soal telah dijawab maka pada layar terakhir akan muncul identitas pengguna beserta nilai total dan kriteria kesantunan pengguna, misalnya mendapat nila 152 dengan kriteria santun atau 75 dengan kriteria sangat tidak santun. Hasil yang berupa identitas pengisi beserta skor yang diperoleh dapat dicetak oleh pengguna alat tes ini.

Skala yang mungkin diperoleh sesuai dengan skor yang dicapai oleh pengguna adalah sebagai berikut.

$\begin{array}{ll}\text { Sangat Santun } & \text { : skor } 200-250 \\ \text { Santun } & \text { : skor } 150-199 \\ \text { Tidak Santun } & \text { : skor } 149-100 \\ \text { Sangat Tidak Santun } & \text { : skor }<100\end{array}$

\section{SIMPULAN}

Dalam penelitian tahun III ini telah dapat dibuat alat ukur kesantunan berbahasa Indonesia dalam tuturan formal bersemuka dalam bentuk VCD interaktif dengan program komputer. Alat ukur ini dibuat berdasarkan draf tentatif indikator kesantunan berbahasa
Indonesia yang telah dihasilkan pada tahun I yang kemudian pada tahun II telah dievaluasi dengan melakukan FGD antara tim peneliti dengan ahli-ahli di bidang pragmatik, sosiolinguistik, dan ahli wacana yang berjumlah 9 orang dan juga dengan guru-guru seDIY yang berjumlah 20 orang.

FGD dilakukan dengan cara para ahli dan para guru tersebut memberikan skor pada jawaban yang sudah diacak oleh tim peneliti. Mereka memberi nilai 5 untuk derajad kesantunan sangat santun, nilai 4 untuk derajad santun, nilai 3 untuk agak santun, nilai 2 untuk tidak santun, dan nilai 1 untuk sangat tidak santun. Penyekoran dilakukan dengan pertimbangan bahwa tujuan pengisian angket bukan sekedar mencari bentuk tuturan yang santun, tetapi membuat peringkat tingkat kesantunan dari bentuk tuturan sangat santun, santun tidak santun dan sangat tidak santun. Dengan demikian dapat dirumuskan skor-skor tingkat kesantunan yang ada sebagai nilai dari wujud tingkat kesantunannya. Uji validitas yang dilakukan adalah untuk menguji validasi kunci yang telah dirumuskan tim peneliti. Validasi ini juga ditempuh untuk mencari keselarasan atau kecocokan jawaban dari tim peneliti dengan jawaban tim ahli. Selanjutnya, alat tes tersebut sekaligus diujicobakan secara terbatas kepada calon pengguna, yang diwakili oleh guru, dosen, mahasiswa dan pemerhati budaya dalam waktu bersamaan karena keterbatasan waktu.

Alat ukur kesantunan ini terdiri dari lima topik bidang interaksi formal bersemuka. Topik-topik tersebut, yaitu topik dalam proses belajar mengajar, topik pertemuan resmi, topik akademik lain non-PBM, topik upacara adat dan seremonial, dan topik transaksi dan negosiasi. Setiap topik berjumlah lima puluh soal dengan lima pilihan jawaban tiap soalnya. Pengguna alat tes ini harus memilih satu jawaban yang mereka anggap tepat. Selanjutnya, jawaban tersebut dicocokkan dengan kunci alat tes tersebut dan dijumlah hasil nilainya. Hasilnya derajad kesantunan pengguna dapat dilihat dari perolehan nilai yang mereka dapatkan. 
Rentang nilai tersebut, yaitu kategori skala sangat santun dengan skor 250-200, skala santun dengan skor 199-150, skala tidak santun dengan skor 149-100, dan skala sangat tidak santun dengan skor $<100$

Pada penelitian tahun III ini alat ukur yang berupa tes tertulis tersebut telah dibuat dalam bentuk VCD interaktif berupa alat tes verbal dengan menggunakan program computer. Pengguna alat tes ini hanya tinggal memasukkan VCD dalam computer yang telah terdapat program Macromedia Flash kemudian mengerjakan soal-soal dalam tes tersebut sesuai perintah yang ada.

\section{DAFTAR PUSTAKA}

Aziz, Aminuddin. 2007. "Aspek-aspek Budaya yang Terlupakan dalam Praktek Pengajaran Bahasa Asing” Bandung: UPI.

Brown, P. dan S. C. Levinson. 1987. Politeness: some universals in language usage. Cambridge: Cambridge University Press.

Cummings, Louise. 2007. Pragmatik: Sebuah Perspektif Multidisiplin. (editor: Abdul Syukur Ibrahim). Yogyakarta: Pustaka Pelajar.

Effendi, S. 1989. "Prinsip-prinsip Pengukuran dan Penyusunan Skala" dalam Singarimbun dan S. Effendi, (Ed) 95-21.

Goffman, E. 1967. Interaction rituals. Garden City: Double Day.

Grice, H. P. 1975. Logic and conversation. Dalam P. Cole dan J.L. Morgan (ed). Syntax and semantics 3: speech acts. NY: Academic Press.

Hymes, D. 1972. Models of the interaction of language and social life. Dalam J.J. Gumperz dan D. Hymes (ed). Directions in sociolinguistics: the ethnography of communication. NY: Holt, Rinehart \& Winston.
Leech, Geoffrey. 1993. Prinsip-prinsip Pragmatik (terj: Oka, M.D.D.) Jakarta : Universits Indoensia.

Levinson, Stephen C. 1983. Pragmatics. Cambridge: Cambridge University Press.

Moleong, Lexy. J. 2000. Metodologi Penelitian Kualitatif. Bandung: PT. Remadja Rosda Karya.

Surahmad, Winarso. 1982. Pengantar Penelitian Ilmiah. Bandung.

Sperber dan Wilson. 1989. Relevance Communication and Cognition. Oxford: Basil:Blackwell.

Wardhaugh, Ronald. 1998. An Introduction to Sociolinguistics. 3rd Edition. Cambridge:Black Well.

Zamzani, 2008. "Peranan Pemahaman Lintas Budaya dalam Pencapaian Fungsi Integratif Bahasa Indonesia". Pidato Pengukuhan Guru Besar, UNY, 12 Maret 2008. Yogyakarta : UNY 